\title{
PENANAMAN KARAKTER ANAK USIA DINI MELALUI METODE DONGENG
}

\author{
Mira Yanti Lubis, ${ }^{1}$ Rani Astria Silvera Harahap, ${ }^{2}$ \& Mancar $^{3}$ \\ STAI Barumun Raya Sibuhuan ${ }^{1,2,3}$ \\ Email: myantilubis87@gmail.com, ${ }^{1}$ raniastriasilvera.harahap89@gmail.com, ${ }^{2}$ \\ marbunmancar@yahoo.co.id, ${ }^{3}$
}

\begin{abstract}
The purpose of this study is to find out if a fairy tale method affects the character planting in early childhood. The method used in this research is a type of qualitative study, the subject is a group of PAUD - A SIT Insan Robbani Sibuhuan District of Barumun, Padang Lawas Regency with a range of ages between 4-5 years and a total of 25 people Consists of 15 men and 10 women. The data collection techniques undertaken are by observation and interview methods. The results of the research obtained is through fairy tale methods applied by the teacher obtained very good results and very effective in the cultivation of early childhood characters. This is evident from the changing attitudes and behaviors of children that show a better and positive direction. This is, of course, supported by good examples and refrretion given by teachers to help and foster early childhood characters.

Keywords : Character Planting, Early childhood, and Fairy tale Methods
\end{abstract}

\begin{abstract}
Abstrak
Penelitian ini bertujuan untuk mengetahui apakah metode dongeng memberikan pengaruh pada penanaman karakter pada anak usia dini. Adapun metode yang digunakan dalam penelitian ini adalah jenis penelitian kualitatif, subjeknya adalah kelompok PAUD - A SIT Insan Robbani Sibuhuan Kecamatan Barumun, Kabupaten Padang Lawas dengan rentang usia antara 4-5 tahun yang berjumlah 25 orang yang terdiri dari 15 orang laki-laki dan 10 orang perempuan. Teknik pengumpulan data yang dilakukan adalah dengan metode observasi dan wawancara. Hasil penelitian yang diperoleh adalah melalui metode dongeng yang diterapkan oleh guru diperoleh hasil yang sangat baik dan sangat efektif dalam penanaman karakter anak usia dini. Hal ini terlihat dari perubahan sikap dan tingkah laku anak yang menunjukkan kearah yang lebih baik dan positif. Hal ini tentunya didukung oleh adanya contoh yang baik dan pembiasan-pembiasan yang diberikan oleh guru untuk membantu dan menumbuhkan karakter anak usia dini.
\end{abstract}

Kata Kunci : Penanaman Karakter, Anak Usia Dini, dan Metode Dongeng 
160 | TAZKIR: Jurnal Penelitian Ilmu-ilmu Sosial dan Keislaman

Vol. 06 No. 1 Juni 2020

\section{PENDAHULUAN}

Undang-Undang menyebutkan anak usia dini adalah anak yang berada pada rentang usia 0-6 tahun. Rentang usia ini biasa disebut dengan masa keemasan (golden age). Pada masa keemasan ini merupakan masa yang sangat efektif untuk mengembangkan berbagai potensi yang dimiliki oleh anak, selain itu pada masa ini juga sangat efektif untuk menanamkan nilai-nilai karakter yang sangat dibutuhkan oleh anak jika sudah dewasa kelak.

Keluarga merupakan tonggak pertama dan yang paling utama mengajarkan berbagai hal pada anak khususnya orangtua. Anak pertama sekali belajar itu adalah dari orangtuanya atau lingkungan keluarganya. Keluarga sangat berperan dalam membentuk karakter anak, mereka merupakan agen sosial yang pertama memberi contoh baik pada anak untuk membentuk karakter anak yang baik. Selaras dengan keluarga guru merupakan agen kedua untuk membentuk karakter anak, karena mereka memiliki posisi strategis sebagai pelaku utama. Guru merupakan sosok idola dan sosok yang bisa ditiru oleh anak didiknya, dan bisa menjadi sumber inspirasi dan motivasi bagi mereka.

Pendidikan karakter merupakan proses pendidikan yang bertujuan untuk mengembangkan nilai, sikap dan perilaku yang memancarkan akhlak mulia dan budi pekerti luhur. Sehingga pendidikan karakter dinilai sangat penting untuk ditanamkan dalam diri anak-anak sejak usia dini, melalui pendidikan karakter anak usia dini dipersiapkan untuk meningkatkan mutu penyelenggaraan dan hasil pendidikan di sekolah yang mengarah pada pembentukan karakter dan akhlak mulia peserta didik secara utuh. Inti dari pendidikan karakter adalah untuk mengembangkan kemampuan sofskill pada anak. Maksudnya adalah pendidikan karakter diharapkan mampu untuk membentuk manusia seutuhnya yang berkarakter, baik dari sikap, sifat dan tingkah laku anak hal ini sabgat penting untuk dikembangkan agar anak mampu memahami, merasakan, dan melaksanakan nilai-nilai kebaikan. Karakter dapat dipancarkan dari hasil keterpaduan antara hati, olah pikir, olah raga keterpaduan antara olah rasa dan karsa seorang individu.

Pendidikan karakter dapat dilakukan pada pendidikan formal, non informal, dan informal. Pada pendidikan formal diselenggarakan pada pendidikan yang paling dasar yaitu PAUD. PAUD merupakan lembaga pendidikan yang merupakan lembaga pendidikan yang memfokuskan pertumbuhan dan perkembangan fisik anak, kecerdasan, sosio emosional, bahasa 
dan komunikasi yang sesuai dengan tahap-tahap perkembangan yang akan dilalui oleh anak usia dini (Santi, 2009).

Pembelajaran dilembaga PAUD sangat bervariasi umumnya dilakukan dengan cara bermain. salah satunya dengan cara bermain peran menggunakan media dongeng, dongeng pada anak usia dini memiliki peran yang sangat penting untuk perkembangan pribadinya secara keseluruhan. Mendongeng mampu mempengaruhi pola pikir anak untuk lebih berkualitas. Karena dongeng/kisah memiliki fungsi pesan yang sangat penting bagi perkembangan jiwa anak. Dalam suatu kisah yang diceritakan dapat menyentuh, memotivasi dan mempengaruhi sikap anak untuk berubah (Meity, 2014). Senada dengan hal itu mendongeng merupakan cara yang paling praktis untuk menanamkan nilainilai kehidupan pada anak karena nilai-nilai yang terkandung pada tokoh-tokoh dongeng dapat dengan mudah dan cepat diserap oleh anak dan tetap membekas sampai ia dewasa.

Menurut Hollowel (dalam Muslich, 2013) ada enam manfaat yang positif dalam mendongeng untuk anak: (1) Mengembangkan imajinasi dan memberikan pengalaman emosional yang mendalam; (2) Memuaskan kebutuhan ekspresi; (3) Menanamkan pendidikan moral tanpa harus menggurui; (4) Menumbuhkan rasa humor yang sehat; (5) Membersiapkan apresiasi sastra; dan (6) Memperluas cakrawala khayalan anak. Senada dengan pendapat di atas ada lima manfaat dongeng untuk anak yaitu: (1) Merangsang kekuatan berpikir; (2) Sebagai media yang efektif; (3) Mengasah kepekaan anak terhadap bunyi-bunyian; (4) Menumbuhkan minat baca; dan (5) Menumbuhkan rasa empati (Latif, 2014). Berdasarkan paparan di atas jelas terlihat bahwa metode dongeng dapat memberikan dampak yang sangat luar biasa dalam diri anak khususnya dalam hal penanaman karakter melalui tokoh-tokoh dongeng yang dikisahkan. selain itu, mendongeng juga dapat merangsang rasa ingin tahu anak dan mengembangkan imajinasi pada anak.

Dalam artikel ini, para peneliti menyampaikan metode penanaman karakter bagi anak-anak usia dini di PAUD SIT Insan Robbani Kecamatan Barumun, Kabupaten Padang Lawas.

\section{METODE PENELITIAN}

Penelitian ini adalah penelitian kualitatif dengan menggunakan jenis pendekatan deskriptif. Sampel penelitian adalah PAUD SIT Insan Robbani 
162 | TAZKIR: Jurnal Penelitian Ilmu-ilmu Sosial dan Keislaman

Vol. 06 No. 1 Juni 2020

Kecamatan Barumun, Kabupaten Padang Lawas dengan subjek penelitian kelompok PAUD- A yang berjumlah 25 orang. Metode observasi, wawancara dan dokumentasi dijadikan sebagai alat dalam pengumpulan data dalam penelitian ini.

Observasi yang digunakan peneliti dalam penelitian ini adalah observasi non-partisipan, peneliti hanya mengamati sampel tanpa ikut terlibat dalam kegiatan yang dilakukan oleh sampel. Pedoman wawancara yang digunakan peneliti adalah berupa pertanyaan-pertanyaan tentang pendidikan karakter. Wawancara yang digunakan adalah semi terstruktur artinya peneliti menggunakan pedoman wawancara tetapi seiring berkembangnya jawaban maka bahan pertanyaan yang akan ditanyakan ikut berkembang juga tanpa harus mengikuti pedoman wawancara yang telah disusun. Dokumentasi yang digunakan adalah segala bentuk dokumen yang mendukung dalam penelitian ini. Uji keabsahan data atau kredibilitas data dilakukan dengan cara: perpanjangan pengamatan, peningkatan ketekunan, trianggulasi, diskusi dengan teman sejawat, analisis kasus negatif, dan member check. Selanjutnya analisis data yang digunakan dalam penelitian ini sesuai dengan arahan Miles dan Huberman (2001) yakni dengan reduksi data (data reduction), penyajian data (data display), dan penggambaran hasil (conclusion drawing).

\section{HASIL PENELITIAN DAN PEMBAHASAN}

\section{Hasil Penelitian}

PAUD SIT Insan Robbani adalah salah satu PAUD yang berada di Pasar Sibuhuan Kecamatan Barumun, Kabupaten Padang Lawas dengan jumlah siswanya sebanyak 25 orang. Kegiatan penanaman karakter di PAUD ini dilakukan melalui metode dongeng dengan menceritakan dongeng-dongeng yang bernapas "ke Islaman" untuk menanamkan karakter yang positif kepada anak didik. Dengan menerapkan metode dongeng ini diharapkan dapat menanamkan nilai-nilai karakter kepada anak. Dalam proses kegiatan mendongeng ini menggunakan cerita-cerita ke Islaman yang menanamkan/mengajarkan nilai-nilai karakter seperti religius, sabar, berbagi kepada sesama, tolong menolong, memiliki empati yang tinggi, tidak mengambil hak orang lain, dan sebagainya.

Penanaman nilai karakter kepada anak dilakukan dengan beberapa cara, salah satunya dengan mendongeng yang dilaksanakan pada saat proses 
pembelajaran berlangsung. Dimana guru mengajarkan dan mengisahkan kepada anak didik tentang kisah-kisah Nabi yang mengandung hal-hal yang bersifat positif dan negatif untuk menjadi bahan perbandingan bagi anak, seperti mengajarkan akhlak terpuji kepada orang tua dengan pemberian contohnya dengan menceritakan kisah Nabi Ibrahim AS. Pesan yang terkandung dalam cerita ini adalah mengajak kita untuk selalu taat kepada Allah SWT dan berbakti kepada kedua orang tua. Sementara nilai-nilai karakter yang muncul dan diperoleh dari kisah ini adalah :

1. Religius

Karakter religius nabi Ibrahim AS terlihat dari ketaatan dan kepatuhan beliau kepada Allah SWT. Hal ini terlihat dari perintah Allah untuk menyembelih anaknya Ismail, perintah ini dilaksanakan dan dipatuhi oleh nabi Ibrahim untuk menjalankan perintah tersebut. Seperti diceritakan dalam QS. Al-Baqarah ayat 131 yang berbunyi " Ketika Tuhannya Berfirman kepadanya : tunduk patuhlah! Ibrahim menjawab: Aku tunduk dan patuj kepada Tuhan semesta alam". Kisah ini mengajarkan kepada kita khususnya anak usia dini untuk selalu patuh pada Allah, ikhlas terhadap ketetapan Allah serta senantiasa taat pada Allah dan juga orangtua.

2. Jujur

Dikisahkan dalam QS. At-Taubah ayat 114 yang berbunyi : "Dan Permintaan ampun dari Ibrahim (Kepada Allah) untuk bapaknya tidak lain hanyalah karena suatu janji yang telah diikrarkannya kepada bapaknya itu". Beliau menepati janjinya untuk selalu mendoakan ayahnya agar mau beriman kepada Allah, namun ketika sang ayah tidak kunjung beriman, maka nabi Ibrahim memutuskan untuk menyerahkan kepada Allah SWT. Ayat di atas mencerminkan bahwa nabi Ibrahim adalah sosok yang jujur dan tapat janji. Begitu juga dengan anak yang sedini mungkin diajarkan dan dididik untuk dapat bersifat jujur dan menepati janji.

3. Toleransi dan Demokrasi

Dalam QS. Ash-Shaffat ayat 102 dijelaskan bahwa: "Ibrahim berkata: "Hai anakku, sesungguhnya aku melihat dalam mimpi bahwa aku menyembelihmu. Maka pikirkanlah apa pendapatmu: ia menjawab: "Hai bapakku, kerjakanlah apa yang diperintahkan kepadamu: Insyaallah kamu akan mendapaiku termasuk orangorang yang sabar". Ayat di atas menjelaskan bahwa Nabi Ibrahim dalam menjalankan dan melaksanakan perintah selalu dilaksanakan dengan sikap 
164 | TAZKIR: Jurnal Penelitian Ilmu-ilmu Sosial dan Keislaman

Vol. 06 No. 1 Juni 2020

toleransi dan demokrasi. Terlihat dari ketika diminta Allah untuk menyembelih anaknya Ismail, Beliau masih meminta pendapat kepada anaknya tentang perintah Allah tersebut. Ini membuktikan bahwa nabi Ibrahim dalam mengambil suatu keputusan selalu didiskusikan dan dipertimbangkan. Karakter demikin yang seharusnya kita ajarkan kepada anak-anak semenjak kecil, agar tumbuh menjadi pribadi yang toleran dan demokratis.

4. Kerja Keras

Kerja keras yang dilakukan nabi Ibrahim AS terlihat dari kerja keras beliau dalam melanjutkan pembangunan ka'bah. Seperti dikisahkan dalam QS. Al-Baqarah ayat 127 yang berbunyi :"Dan ingatlah, ketika Ibrahim meninggikan (membina) dasar-dasar baitullah bersama Ismail (seraya berdoa): "Ya Tuhan kami terimalah daripada kami (amalan kami), sesungguhnya Engkaulah yang Maha Mendengar lagi Maha Mengetahui". Ayat di atas menjelaskan bagaiman perjuangan dan kerja keras nabi Ibrahim dan Ismail dalam menyelesaikan pembangunan ka'bah. Mereka saling bergotong royong, bahu membahu agar bangunan baitullah ini dapat diselesaikan. Demikian yang harus diajarkan kepada anak, menanamkan sifat kerja keras dalam menggapai sesuatu dan juga menuntut ilmu (belajar).

5. Peduli

Dalam QS. Maryam ayat 45 yang berbunyi: "Wahai bapakku, sesungguhnya aku khawatir bahwa kamu akan ditimpa azab dari Tuhan yang Maha Pemurah, maka kamu menjadi kawan bagi syaithan". Hal ini menjelaskan bahwa walaupun ayah nabi Ibrahim pekerja dan penyembah berhala, tetapi beliau tetap mengingatkan dan peduli kepada sang ayah untuk dapat bertobat dan beriman kepada Allah SWT. Demikian pula terhadap anak usia dini, sikap peduli harus ditanamkan pada diri anak.

Dari hasil penelitian yang telah dilakukan peneliti menunjukkan bahwasanya metode dongeng memiliki pengaruh yang sangat signifikan dalam penanaman karakter dan perkembangan anak, hal ini terlihat dari perubahan tingkah laku, sifat, dan tutur kata anak. dari aspek tingkah laku anak mulai peduli dengan temannya dan mau bekerja sama dalam bermain dan belajar. Dari aspek sifat anak terlihat dari ketika guru menegur anak mereka patuh dan mendengarkan guru. Selain itu, anak tidak lagi mudah marah dan menangis jika ada hal yang tidak sesuai dengan hatinya sementara dari segi tutur kata anak 
sudah mulai menggunakan kata-kata yang sopan seperti penggunaan kata "aku" menjadi "ana".

\section{Pembahasan}

Pendidikan karakter pada anak usia dini memiliki makna lebih tinggi dari pendidikan moral karena tidak hanya berkaitan dengan masalah benar dan salah, tetapi menanamkan bagaimana supaya menjadi kebiasaan (habit) bagi anak tentang berbagai perilaku yang baik dalam kehidupan, sehingga anak memiliki kesadaran, dan pemahaman yang tinggi serta kepedulian dan komitmen untuk menerapkan kebajikan dalam kehidupan sehari-hari. Karakter merupakan sifat yang alami bagi anak usia dini untuk merespons situasi secara bermoral yang harus diwujudkan dalam tindakan yang nyata melalui pembiasaan sejak dini.

Keberhasilan dalam menanamkan pendidikan karakter pada anak sejak dini sangat tergantung pada ada tidaknya kesadaran, pemahaman, kepedulian, dan komitmen berbagai pihak. Menurut Foester dalam Masnur (2013) ciri pendidikan karakter sebagai berikut: (1) keteraturan interior dimana setiap tindakan diukur berdasar hierarki nilai, (2) koherensi yang memberi nilai keberanian, membuat seseorang teguh pada prinsip, (3) otonomi, dan (4) keteguhan dan kesetiaan. Sedangkan rumusan nilai karakter adalah: (1) religius, (2) jujur, (3) toleransi, (4) disiplin, (5) kerja keras, (6) kreatif, (7) mandiri, (8) demokratis, (9) rasa ingin tahu, (10) semangat kebangsaan, (11) cinta tanah air, (12) menghargai prestasi, (13) bersahabat atau komunikatif, (14) cinta damai, (15) gemar membaca, (16) peduli lingkungan, (17) peduli sosial, dan (18) tanggung jawab. (TimPendidikanKarakterKemdiknas, 2010).

Dongeng mempunyai peran penting dalam pembentukan karakter pada anak, dongeng dapat menjadi jembatan utama yang efektif dalam menyampaikan pengajaran kepada anak, dongeng mampu menciptakan efek fantasi yang kuat karena sangat dekat dan erat sekali dengan dunia imajinasi serta disukai oleh anak karena dengan menggunakan metode dongeng anak merasa tidak dinasehati atau digurui baik itu oleh orang tua maupun guru. Dongeng itu sendiri adalah sebuah cerita yang sifatnya asli atau fakta (Depdiknas, 2010).

Metode dongeng merupakan kegiatan yang menyenangkan bagi anak dan dapat memberikan pengalaman belajar yang lebih berwarna pada anak (Fitroh \& 
166 | TAZKIR: Jurnal Penelitian Ilmu-ilmu Sosial dan Keislaman

Vol. 06 No. 1 Juni 2020

Sari, 2015). Kegiatan ini juga sangat menyenangkan karena melalui metode dongeng materi yang berat akan menjadi lebih ringan untuk disampaikan dan mudah untuk dipahami anak. Begitupun dalam hal pendidikan dan proses pembelajaran menjadi lebih lancar dan kondusif.

Pelaksanaan pembelajaran dengan menggunakan metode dongeng dapat meningkatkan pengetahuan dan kemampuan bagi anak khususnya dalam hal kemampuan berkomunikasi, anak yang sering mendengar dongeng lebih memiliki kosakata yang lebih banyak dan bahasanya juga lebih beragam dibanding anak yang jarang mendengar dongeng. Selain itu, anak juga lebih termotivasi untuk berubah ke arah yang lebih baik lagi sesuai dengan tokohtokoh positif yang ada pada dongeng (Aulia, 2018). Anak-anak dapat menangkap nilai-nilai yang muncul dari cerita yang disampaikan kepada mereka, sehingga akan semakin mudah untuk menanamkan karakter yang baik kepada mereka. Penanaman nilai karakter ini amat penting, karena sumber daya manusia jika hanya menguasai ilmu pengetahuan tanpa memiliki karakter yang baik akan menghancurkan bangsa dan negara ini (Hasibuan, 2014). Lebih jauh yang penting untuk dilakukan adalah melakukan integrasi antara pendidikan dan karakter akan menjadikan hasil pendidikan tersebut lebih baik (Zulhimma, 2014), dengan demikian maka pendidikan tentu akan menghasilkan anak didik yang penuh karakter. Olehkarenanya, penanaman nilai karakter sejak ini penting sekali, hal ini dilakukan melalui proses pendidkan yang dijanali oleh anak didik dalam rangka menciptakan generasi bangsa yang lebih baik.

Penanaman karakter melalui cerita tentu sangat menarik bagi anak-anak usia dini, semakin sering metode dongeng dikisahkan kepada anak-anak maka semakin baik proses berpikir anak ke arah yang lebih konkrit dan mampu untuk berimajinasi. Dongeng dengan kisah yang baik membawa perubahan yang baik pula untuk kehidupan anak, karena di dalamnya mengandung pesan moral yang baik yang dapat dijadikan contoh dan tauladan kepada anak. Sementara dongeng dengan kisah yang kurang baik dijadikan pembelajaran bagi anak. Anak diajarkan dan diberikan pemaham tentang akibat dari perbuatan buruk tersebut. Diharapkan dengan dongeng-dongeng yang dikisahkan anak mampu menyerap dan mampu mengambil hikmah dari cerita yang dikisahkan, sehingga perkembangan anak dapat berkembang baik dari segi moral, bahasa dan sosial emosional anak. 


\section{PENUTUP}

Kesimpulan dari hasil penelitian yang dilakukan di PAUD SIT Insan Robbani Sibuhuana adalah: mendongeng merupakan salah satu metode yang sangat efektif untuk menanamkan karakter pada anak usia dini, serta dengan mendongeng dapat merangsang rasa ingin tahu anak dan mengembangkan imajinasi anak dalam berpikir dan bertingkah laku. Di samping itu, dengan diterapkannya metode dongeng dalam pembelajaran di lembaga pendidikan mampu membawa perubahan ke arah yang positif, khususnya pada pelaksanaan pembelajaran menjadi lebih mudah untuk dikondisikan dan diarahkan. Anakanak menjadi mudah diatur dan dibimbing untuk dapat mengikuti pembelajaran dengan baik dan kondusif. Begitu juga dengan tingkah laku dalam bekerjasama dan bersosial, anak tumbuh menjadi pribadi yang sabar, mau berbagi, suka menolong dan peduli kepada teman-temannya.

\section{ACKNOWLEDGMENTS}

Ucapan banyak terima kasih tim peneliti haturkan kepada SIT PAUD Insan Robbani yang telah membantu tim peneliti mulai dari proses penyusunan tulisan sampai dengan memperoleh hasil penelitian. Kepada pihak kampus tim peneliti juga mengucapkan banyak terima kasih karena telah memfasilitasi dan memberikan banyak kemudahan kepada tim peneliti sehingga penelitian dapat terselesaikan dengan baik dan tepat waktu. 
168 | TAZKIR: Jurnal Penelitian Ilmu-ilmu Sosial dan Keislaman

Vol. 06 No. 1 Juni 2020

\section{DAFTAR PUSTAKA}

Aulia, L. R. (2018). Membangun Karakter Bangsa Sejak Dini Melalui Metode Bercerita. Proceedings of The 3 Rd Annual Conference on Islamic Early Childhood Education.

http://ejournal.uinsuka.ac.id/tarbiyah/conference/index.php/aciece/aciece3

Depdiknas. (2010). Prinsip Perkembangan Bahasa pada Anak. Depdiknas.

Fitroh, S. F., \& Sari, E. D. N. (2015). Dongeng sebagai Media Penanaman Karakter pada Anak Usia Dini. PG PAUD Trunojoyo, 2(2).

Hasibuan, M. (2014). Makna dan Urgensi Pendidikan Karakter. In FITRAH:Jurnal Kajian Ilmu-ilmu Keislaman (Vol. 8, Issue 1). http://jurnal.iainpadangsidimpuan.ac.id/index.php/F/article/view/339

Latif, M. A. (2014). Mendongeng Mudah dan Menyenangkan Aplikasi Penerapan dalam Mendukung Pembelajaran. PT. Luxima Metro Media.

Meity, H. I. (2014). Meningkatkan Kecerdasan Anak Usia Dini melalui Dongeng. PT. Luxima Metro Media.

Miles, M. B., \& Huberman, A. M. (2001). Analisis Data Kualitatif. Universitas Indonesia.

Muslich, M. (2013). Pendidikan Karakter Menjawab Tantangan Krisis Multidimensional. PT. Bumi Aksara.

Santi, D. (2009). Pendidikan Anak Usia Dini antara Teori dan Praktik. Indeks.

TimPendidikanKarakterKemdiknas. (2010). Grand Design Pendidikan Karakter. Kemdiknas.

Zulhimma, Z. (2014). Implementasi Pendidikan Karakter dengan Pola Integralistik dalam Membentuk Kepribadian Siswa di SDIT Bunayya Padangsidimpuan. In TAZKIR: Jurnal Penelitian Ilmu-ilmu Sosial dan Keislaman (Vol. 9, Issue 2). http://jurnal.iainpadangsidimpuan.ac.id/index.php/TZ/article/view/101 